MaPan : Jurnal Matematika dan Pembelajaran

p-ISSN: 2354-6883 ; e-ISSN: 2581-172X

Volume 6, No 2, December 2018 (265-273)

DOI: https://doi.org/10.24252/mapan.2018v6n2a11

\title{
MICROSOFT POWERPOINT PADA APLIKASI ANDROID DALAM PENINGKATAN PEMAHAMAN KONSEP MATEMATIS
}

\author{
Ruhban Masykur1), Lidia Ramadhani Aulia'2), Iip Sugiharta3) \\ 1,2UIN Raden Intan Lampung \\ 1,2Jl. Letnan Kolonel H. Endro Suratmin, Sukarame, Bandar Lampung \\ E-mail: $\underline{\text { rmasykur@yahoo.co.id }}^{1}{ }^{\text {, lidiaramadhani19@gmail.com }}{ }^{2)}$ \\ iipsugiharta@gmail.com $\left.{ }^{3}\right)$
}

Submitted: 29-09-2018, Revised: 28-12-2018, Accepted: 31-12-2018

\begin{abstract}
Abstrak:
Pemahaman konsep merupakan salah satu indikator hasil belajar peserta didik, sehingga tujuan dari penelitian ini untuk mengetahui peningkatan pemahaman konsep matematis peserta didik dengan menggunakan microsoft powerpoint pada aplikasi android. Jenis penelitian yang digunakan yaitu eksperimen semu (quasi eksperimental design), dan menggunakan desain penelitian non equivalent control group. Teknik analisis data yang digunakan adalah uji n-gain dan uji hipotesis nya menggunakan Anova satu jalur. Pengujian hipotesis menyatakan bahwa Ho ditolak, sehingga terdapat peningkatan pemahaman konsep matematis menggunakan microsoft powerpoint pada aplikasi andorid dengan taraf n-gain pada interprestasi tinggi.
\end{abstract}

Kata Kunci: Microsoft Powerpoint, Android, Pemahaman Konsep Matematis

\section{MICROSOFT POWERPOINT ON ANDROID APPLICATION IN IMPROVING THE UNDERSTANDING OF MATHEMATICAL CONCEPTS}

\begin{abstract}
:
Concept understanding is one indicator in improving student learning outcomes, so the aim of this research is to find out the improvement of students' mathematical concept understanding by using Microsoft Powerpoint on Android applications. The type of research used is quasiexperimental (quasi experimental design), and uses the non equivalent control group. The data analysis technique used in the study is the n-gain test and hypothesis testing using one-way ANOVA. Which states that Ho is rejected, so there is an increase in understanding of mathematical concepts using microsoft powerpoint on andorid applications with an n-gain level at high interpretation.
\end{abstract}

Keywords: Microsoft Powerpoint, Android, and Understanding Mathematical Concepts

How to Cite: Masykur, R., Aulia, L. R. \& Sugiharta, I. (2018). Microsoft Powerpoint pada Aplikasi Android dalam Peningkatan Pemahaman Konsep Matematis. MaPan: Jurnal Matematika dan Pembelajaran, 6(2), 265-273.

Copyright @ 2018, MaPan : Jurnal Matematika dan Pembelajaran 
$\mathrm{B}$ elajar merupakan proses kegiatan untuk dapat memiliki perubahan tingkah laku dari hasil pengalaman dalam berinteraksi terhadap lingkungannya yang menyangkut kognitif, afektif, dan psikomotorik. Peserta didik mengalami sendiri proses dari tidak tahu menjadi tahu dalam proses pembelajaran, salah satunya pembelajaran matematika (Slameto, 2003). Pembelajaran matematika sangat penting bagi peserta didik, berdasarkan pada tujuan pembelajaran matematika di pendidikan dasar sampai menengah yaitu untuk mempersiapkan peserta didik dapat selalu berkembang secara logis, rasional, kritis, cermat, jujur, efisien dan efektif dalam dunia pendidikan (Hasbullah, 2011). Berbagai media pembelajaran yang telah dikembangkan dalam pembelajaran matematika, salah satunya pemanfaatan program microsoft powerpoint.

Microsoft powerpoint adalah suatu software yang dikembangkan secara khusus untuk membuat program multimedia yang menarik, dan juga mudah dalam pembuatan serta penggunaannya (Arsyad, 2013). Microsoft powerpoint dapat digunakan atau dimanfaatkan sebagai media penunjang dalam proses pembelajaran, dengan powerpoint para pendidik dapat mendesain aplikasi yang dapat membantu para peserta didik untuk lebih mudah berinteraksi dengan materi pelajaran yang disampaikan (Mangkulo, 2011). Para pendidik dituntut agar mampu menciptakan alat-alat dan menggunakan media yang tersedia disekolah sebagai penunjang dalam meningkatkan pemahaman konsep matematis peserta didik untuk pembelajaran matematika salah satunya penggunaan media pembelajaran pada aplikasi android.

Sistem operasi pada android yang banyak diminati di masyarakat adalah yang memiliki kelebihan seperti sifat open source yang dapat memberikan suatu kebebasan untuk para pengembang dalam menciptakan suatu aplikasi (Anggraeni \& Kustijono, 2013). Penggunaan perangkat seluler dengan sistem operasi seperti system linux dirancang dengan menggunakan layar sentuh seperti smartphone dengan didasarkan pada manipulasi langsung menggunakan tindakan di dunia nyata seperti menggesek, mengetuk, dan membalikkan. (Rahardi, 2014). Berdasarkan penelitian yang telah dilakukan Rohmi Julia bahwa media pembelajaran android memiliki keunggulan tersendiri, yaitu keunggulannya dapat digunakan pada perangkat berbasis Android dan Windows dan menampilkan contoh-contoh dengan tingkat penampilan materi yang beragam serta dilengkapi dengan gambar dan juga animasi dalam membantu peserta didik untuk memahami materi (Purbasari, Kahfi, \& Yunus, 2013).

Pemahaman konsep pada pembelajaran matematika merupakan aspek yang sangat penting, maka peserta didik harus mengerti akan konsep matematika, dengan cara dapat menerjemahkan, menerangkan, dan menyimpulkan suatu konsep matematika berdasarkan pembentukan dari pengetahuanya sendiri, dan bukan hanya menghafal. Peserta didik bisa 
menemukan dan memberikan penjelasan mengenai konsep dengan konsep lainnya (Utari, Fauzan, \& Rosha, 2012). Pemahaman konsep digunakan dalam proses belajar karena dapat menyelesaikan permasalahan yang ada kaitannya dengan konsep yang telah dimiliki. Peserta didik juga tidak hanya sebatas mengenal dalam pemahaman konsep, tetapi juga harus mengerti bagaimana menghubungkan satu konsep dengan konsep yang lain (Hamdani, Kurniati, \& Sakti, 2012).

Sejalan dengan penelitian yang telah dilakukan menunjukkan bahwa penggunaan media pembelajaran microsoft powerpoint dapat meningkatkan hasil belajar siswa (Asmadji, n.d.). Nancy angko mengatakan bahwa media pembelajaran matematika menggunakan media powerpoint bersama-sama dengan lembar kerja siswa menarik (Angko \& Mustaji, 2013). M. Yahya mengatakan bahwa media microsoft powerpoint dilengkapi dengan metode pembelajaran problem posing dapat menigkatkan prestasi belajar dan interaksi sosial(Ghufroni, Haryono, \& Hastuti, 2013). Srimaya mengatakan bahwa peningkatan aktivitas belajar dapat ditingkatkan dengan media pembelajaran powerpoint. (Srimaya, 2017). Sehingga peneliti memiliki tujuan untuk mengetahui peningkatan pemahaman konsep matamatis menggunakan microsoft powerpoint yang terdapat pada smartphone berbasis andorid.

\section{METODE PENELITIAN}

Jenis penelitian yang digunakan pada penelitian ini adalah penelitian eksperimen semu (quasi eksperimental design), dan menggunakan desain penelitian non equivalent control group. Penelitian ini dilakukan di SMP Kartika II-2 Bandar Lampung, pada bulan Agustus 2018. Populasi pada penelitian ini adalah seluruh peserta didik kelas VIII SMP Kartika II-2 Bandar Lampung tahun ajaran 2018/2019 sebanyak 7 kelas dengan total perserta didik 229. Sampel pada penelitian ini sebanyak tiga kelas yaitu masing-masing yang berjumlah 32 peserta didik, Untuk kelas eksperimen satu yaitu kelas VIII 5, kelas eksperimen dua yaitu kelas VIII 7 sedangkan kelas kontrol yaitu kelas VIII 6. Teknik pengumpulan data yang digunakan yaitu: (1) wawancara, mengumpulkan data mengenai proses belajar mengajar dan hasil belajar siswa juga sebagai informasi mengenai data dan kondisi objektif sekolah. (2) observasi, yang dilakukan selama proses pembelajaran berlangsung untuk mengamati secara langsung proses pembelajaran di kelas dengan microsoft powerpoint pada aplikasi android. (3) tes yang digunakan berupa soal pemahaman konsep sebagai cara dalam mengetahui peningkatan pemahaman konsep matematis peserta didik setelah mempelajari materi pada microsoft powerpoint menggunakan aplikasi android. (4) dokumentasi, digunakan sebagai penguat data untuk mengetahui kemampuan awal siswa, dan kemampuan siswa selama proses pembelajaran yang dilakukan. Instrumen penelitian ini menggunakan uji prasyarat yang meliputi uji validitas, dan reliabilitas. Teknik 
analisis data meliputi uji normalitas gain dan uji homogenitas gain dengan taraf signifikansi 5\% (Dinda, 2016). Sedangkan uji hipotesis nya menggunakan One Way Anova (Budiyono, 2015).

\section{HASIL PENELITIAN DAN PEMBAHASAN}

Penelitian ini diawali dengan memberikan pretest kemampuan pemahaman konsep matematis. Hasil pretest secara deskriptif terdapat pada tabel 1.

Tabel 1. Hasil Deskripsi Data Pemahaman Konsep Matematis Kelas Eksperimen dan Kontrol

\begin{tabular}{|c|c|c|c|c|c|c|c|}
\hline \multirow[b]{2}{*}{ Kelompok } & \multirow[b]{2}{*}{$X_{\text {maks }}$} & \multirow[b]{2}{*}{$X_{\min }$} & \multicolumn{3}{|c|}{$\begin{array}{c}\text { Ukuran Tendensi } \\
\text { Sentral }\end{array}$} & \multicolumn{2}{|c|}{$\begin{array}{l}\text { Ukuran } \\
\text { Variasi }\end{array}$} \\
\hline & & & $\bar{X}$ & $\mathrm{M}_{\mathrm{o}}$ & $\mathrm{M}_{\mathrm{e}}$ & $\mathrm{R}$ & $\mathrm{Sd}$ \\
\hline Eksperimen 1 & 53 & 33 & 41.96 & 43 & 43 & 20 & 5.18 \\
\hline Eksperimen 2 & 53 & 33 & 41.71 & 40 & 41.5 & 20 & 5.32 \\
\hline Kontrol & 53 & 33 & 42.31 & 45 & 43 & 20 & 5.36 \\
\hline
\end{tabular}

Hasil pretest menunjukkan bahwa kelas eksperimen dan kelas kontrol sama untuk nilai tertinggi, yaitu 53 sedangkan nilai terendahnya, kelas eksperimen memiliki nilai terendah yang sama dengan kelas kontrol 33 ini mengakibatkan adanya kesamaan pada rata-rata hasil pretest. Kelas eksperimen satu memiliki rata-rata 41,96 dan kelas eksperimen dua memiliki rata-rata 41,71 sedang kelas kontrol 42,31 ini menunjukkan bahwa terdapat kesamaan kemampuan antara kelas eksperimen dengan kelas kontrol.

Setelah dilakukan pretest untuk menentukan kemampuan pemahaman konsep matematis diadakannya posttest. Hasil posttest secara deskriptif dapat dilihat dari tabel 2.

Tabel 2. Hasil Deskripsi Data Posttest Kelas Eksperimen dan Kontrol

\begin{tabular}{cccccccc}
\hline & & & \multicolumn{3}{c}{$\begin{array}{c}\text { Ukuran Tendensi } \\
\text { Sentral }\end{array}$} & $\begin{array}{c}\text { Ukuran Variansi } \\
\text { Kelompok }\end{array}$ \\
\cline { 3 - 8 } Kelompok & $\mathbf{X}_{\max }$ & $\mathbf{X}_{\min }$ & $\bar{X}$ & $\mathrm{M}_{\mathrm{o}}$ & $\mathrm{M}_{\mathrm{e}}$ & $\mathrm{R}$ & $\mathrm{Sd}$ \\
\hline Eksperimen 1 & 98 & 65 & 83.18 & 83 & 83 & 33 & 8.61 \\
Eksperimen 2 & 93 & 58 & 76.53 & 80 & 76.5 & 35 & 8.03 \\
Kontrol & 85 & 53 & 70.84 & 70 & 70 & 32 & 7.84 \\
\hline
\end{tabular}

Hasil postest menunjukkan bahwa tidak berbeda jauh antara nilai tertinggi kelas eksperimen dengan kelas kontrol, kelas eksperimen satu yaitu 
98, kelas eksperimen dua yaitu 93 dan kelas kontrol 85 sedangkan dengan nilai terendahnya, kelas eksperimen satu memiliki nilai terendah 65, kelas eksperimen dua memiliki nilai terendah 58 dan kelas kontrol 53 ini mengakibatkan adanya perbedaan pada rata-rata hasil postest setelah diberikan perlakuan atau strategi pembelajaran yang berbeda. Kelas eksperimen satu memiliki rata-rata 83,18 dan kelas eksperimen dua memiliki rata-rata 76,53 sedang kelas kontrol 70,84 ini menunjukkan bahwa adanya perbedaan kemampuan antara kelas eksperimen dengan kelas kontrol setelah diberi perlakuan yang berbeda.

Setelah dilakukannya pretest dan posttest kemudian mencari n-gain, yaitu untuk melihat selisih n-gain pada peningkatan kemampuan pemahaman konsep matematis setelah dilakukan pembelajaran. Hasil n-gain secara deskriptif terdapat pada tabel 3 .

Tabel 3. Hasil Deskripsi Data N-gain Kelas Eksperimen dan Kontrol

\begin{tabular}{cccccccc}
\hline \multirow{2}{*}{ Kelompok } & $\mathbf{X}_{\max }$ & $\mathbf{X}_{\text {min }}$ & \multicolumn{2}{c}{$\begin{array}{c}\text { Ukuran Tendensi } \\
\text { Sentral }\end{array}$} & \multicolumn{2}{c}{$\begin{array}{c}\text { Ukuran } \\
\text { Variansi } \\
\text { Kelompok }\end{array}$} \\
\cline { 3 - 8 } & & & $\bar{X}$ & $\mathrm{M}_{\mathrm{o}}$ & $\mathrm{M}_{\mathrm{e}}$ & $\mathrm{R}$ & $\mathrm{Sd}$ \\
\hline Eksperimen 1 & 0.97 & 0.26 & 0.705 & 0.725 & 0.726 & 0.711 & 0.164 \\
Eksperimen 2 & 0.89 & 0.24 & 0.589 & 0.583 & 0.6 & 0.655 & 0.155 \\
Kontrol & 0.77 & 0.16 & 0.489 & 0.477 & 0.479 & 0.609 & 0.146 \\
\hline
\end{tabular}

Hasil n-gain menunjukkan bahwa tidak berbeda jauh antara nilai tertinggi kelas eksperimen dengan kelas kontrol, kelas eksperimen satu yaitu 0,97, kelas eksperimen dua yaitu 0,89 dan kelas kontrol 0,77 sedangkan nilai terendahnya, kelas eksperimen satu memiliki nilai terendah 0,26, kelas eksperimen dua memiliki nilai terendah 0,24 dan kelas kontrol 0,16 ini mengakibatkan adanya perbedaan pada rata-rata hasil $n$-gain setelah diberikan perlakuan atau strategi pembelajaran yang berbeda. Kelas eksperimen satu memiliki rata-rata 0,705 dan kelas eksperimen dua memiliki rata-rata 0,589 sedang kelas kontrol 0,489 ini menunjukkan bahwa adanya peningkatan kemampuan antara kelas eksperimen dengan kelas kontrol setelah diberikan perlakuan yang berbeda bahwa interprestasinya tinggi dan sedang. 
Hasil uji normalitas n-gain terdapat pada tabel 4 dan tabel 5 .

Tabel 4. Hasil Uji Normalitas N-Gain Kelas Eksperimen

\begin{tabular}{ccccccc}
\hline & $\bar{X}$ & $\mathbf{S}$ & $\mathbf{A}$ & Lhitung & Ltabel & Keputusan Uji \\
\cline { 2 - 7 } Eksperimen 1 & 0.70 & 0.164 & 0.05 & 0.0589 & 2.0369 & $\mathrm{H}_{0}$ diterima \\
Eksperimen 2 & 0.58 & 0.155 & 0.05 & 0.0691 & 2.0369 & $\mathrm{H}_{0}$ diterima \\
\hline
\end{tabular}

Berdasarkan pada tabel di atas diketahui bahwa hasil data n-gain kelas eksperimen satu dengan rata-rata (mean) sebesar 0.70 dan kelas eksperimen dua dengan rata-rata (mean) sebesar 0.58. Dengan Lhitung $=0.0589$ pada kelas eksprimen satu dan Lhitung $=0.0691$ pada kelas eksprimen dua. Sehingga Lhitung $\leq$ Ltabel, untuk sampel sebanyak 32 peserta didik dengan taraf signifikan $a=$ 0.05. Yang menyatakan bahwa $\mathrm{H}_{0}$ diterima maka sampel berasal dari populasi berdistribusi normal.

Tabel 5. Hasil Uji Normalitas N-gain Kelas Kontrol

\begin{tabular}{ccccccc}
\hline \multirow{3}{*}{ Kelas Kontrol } & $\bar{X}$ & $\mathbf{S}$ & $\mathbf{A}$ & $\mathbf{L}_{\text {hitung }}$ & L tabel & Keputusan Uji \\
\cline { 2 - 7 } & 0.48 & 0.146 & 0.05 & 0.0918 & 2.0369 & $\mathrm{H}_{0}$ Diterima \\
\hline
\end{tabular}

Berdasarkan pada tabel di atas diketahui bahwa hasil data n-gain kelas kontrol dengan rata-rata (mean) sebesar 0.48 dengan taraf signifikan $a=0.05$ untuk sampel sebanyak 32 peserta didik. Sehingga didapat $L_{\text {hitung }}=0.0918$ dan $\mathrm{L}_{\text {tabel }}=2.0369$. sehingga $\mathrm{H}_{0}$ diterima karena $\mathrm{L}_{\text {hitung }} \leq \mathrm{L}_{\text {tabel }}$ yang artinya sampel berasal dari populasi berdistribusi normal.

Tabel 6. Hasil Uji Homogenitas N-Gain Kelas Eksperimen dan Kontrol

\begin{tabular}{ccccc}
\hline Kelompok & $\mathbf{N}$ & $\mathbf{F}_{\text {hitung }}$ & $\mathbf{F}_{\text {tabel }}$ & Keputusan \\
\hline Kelas eksperimen 1 & 32 & & & \\
Kelas eksperimen 2 & 32 & 0.4223 & 1.9858 & $\mathrm{H}_{0}$ diterima \\
Kelas kontrol & 32 & & & \\
\hline
\end{tabular}

Berdasarkan dari hasil perhitungan pada tabel di atas diperoleh $F_{h i t u n g}=$ 0.4223 dan $F_{\text {tabel }}=1.9858$ terlihat bahwa $\mathrm{F}_{\text {hitung }} \leq \mathrm{F}_{\text {tabel. }}$ Sehingga $\mathrm{H}_{0}$ diterima dan sampel berasal dari populasi yang homogen. 
Tabel 7. Hasil Uji Hipotesis One Way Anova dari N-gain Kelas Eksperimen dan Kelas Kontrol

\begin{tabular}{cccccc}
\hline Kelompok & $\begin{array}{c}\text { Rata- } \\
\text { rata }\end{array}$ & Varians & F $_{\text {hitung }}$ & $\mathbf{F}_{\text {tabel }}$ & Keputusan \\
\hline Eksperimen 1 & 0.70 & 0.0269 & & & \\
Eksperimen 2 & 0.58 & 0.0242 & 15.23 & 3.094 & $\mathrm{H}_{0}$ ditolak \\
$\quad$ Kontrol & 0.48 & 0.0213 & & & \\
\hline
\end{tabular}

Berdasarkan uji hipotesis n-gain kelas eksperimen satu memiliki rata-rata 0,70 dan kelas eksperimen dua sebesar 0,58 serta kelas kontrol 0,48 dari kemampuan pemahaman konsep matematis dapat dilihat bahwa $\mathrm{T}_{\text {hitung }}=15.23$ $>\mathrm{T}_{\text {tabel }}=3.094$. Dengan taraf signifikan $\mathrm{a}=0.05 \mathrm{H}_{0}$ ditolak. Sehingga dapat ditarik kesimpulan bahwa kemampuan pemahaman konsep matematis peserta didik meningkat melalui microsoft powerpoint pada aplikasi android.

\section{SIMPULAN}

Berdasarkan hasil dan pembahasan yang telah dilakukan dapat ditarik kesimpulan bahwa terdapat peningkatan pemahaman konsep matematis menggunakan microsoft powerpoint pada aplikasi andorid dengan taraf interprestasi tinggi dan terdapat peningkatan pemahaman konsep matematis menggunakan microsoft powerpoint berada pada taraf interprestasi sedang. Berdasarkan penelitian yang telah dilakukan bahwa microsoft powerpoint pada aplikasi android memiliki keunggulan dan kekurangan, yakni keunggulannya media pembelajaran tersebut sangat mudah untuk digunakan tanpa harus memiliki koneksi internet serta mudah dalam penggunaan. Kekurangan dari penelitian ini tidak bisa digunakan dalam pembelajaran yang peserta didik nya tidak memiliki android.

\section{DAFTAR PUSTAKA}

Anggraeni, R. D., \& Kustijono, R. (2013). Pengembangan media animasi fisika pada materi cahaya dengan aplikasi flash berbasis android. Jurnal Pendidikan Fisika Dan Aplikasinya, 3(1), 11-18.

Angko, N., \& Mustaji. (2013). Pengembangan bahan ajar dengan model addie untuk mata pelajaran matematika kelas 5 SD Mawar Sharon Surabaya. Jurnal Kwangsan, 1-15.

Arsyad, A. (2013). Media pembelajaran. Jakarta: PT Raja Grafindo Persada. 
Asmadji, H. (n.d.). Penggunaan media pembelajaran power point untuk meningkatkan hasil belajar IPA materi pesawat sederhana siswa kelas $V_{C}$ SDN Ketabang I Surabaya, 1-14.

Budiyono, B. (2015). Statistik untuk penelitian. Surakarta: Sebelas Maret University Press.

Dinda, P. D. (2016). Pembelajaran learning cycle 5E berbantuan geogebra terhadap kemampuan pemahaman konsep matematis. Al-Jabar: Jurnal Pendidikan Matematika, 7(2), 191-202.

Ghufroni, M. Y., Haryono, H., \& Hastuti, B. (2013). Upaya peningkatan prestasi belajar dan interaksi sosial siswa melalui penerapan metode pembelajaran problem posing dilengkapi media power point pada materi pokok stoikiometri kelas x sma batik 2 surakarta tahun pelajaran 2012/2013. Junal Pendidikan Kimia, 2(3), 114-121.

Hamdani, D., Kurniati, E., \& Sakti, I. (2012). Pengaruh model pembelajaran generatif dengan menggunakan alat peraga terhadap pemahaman konsep cahaya kelas VIII di SMP Negeri 7 Kota Bengkulu. Jurnal Exacta, 10(1), 7988.

Hasbullah. (2011). Dasar-dasar ilmu pendidikan. Jakarta: PT Raja Grafindo Persada.

Mangkulo, H. A. (2011). Aplikasi belajar interaktif dengan powerpoint. Jakarta: PT Elex Media Komputindo.

Purbasari, R. J., Kahfi, M. S., \& Yunus, M. (2013). Pengembangan aplikasi android sebagai media pembelajaran matematika pada materi dimensi tiga untuk siswa SMA Kelas X. Jurnal Online Universitas Negeri Malang, 1(4).

Rahardi, D. R. (2014). Pengukuran usability sistem menggunakan use questionnaire pada aplikasi android. Jurnal Sistem Informasi, 6(1), 661-671.

Slameto. (2003). Belajar dan faktor-faktor yang mempengaruhinya. Jakarta: PT Rineka Cipta.

Srimaya, S. (2017). Efektivitas media pembelajaran powerpoint untuk meningkatkan motivasi dan hasil belajar biologi siswa. Jurnal Biotek, 5(1), 53-68. 
Utari, V., Fauzan, A., \& Rosha, M. (2012). Peningkatan kemampuan pemahaman konsep melalui pendekatan PMR dalam pokok bahasan prisma dan limas. Jurnal Pendidikan Matematika, 1(1), 33-38. 